\title{
The Emergence of Modern Biotechnology in China
}

\author{
Shaheen Emmanuel Lakhan \\ Global Neuroscience Initiative Foundation, Los Angeles, USA
}

\author{
slakhan@gnif.org
}

\begin{abstract}
Science and technology of Republican China (1912-1949) often replicated the West in all hierarchies. However, in 1949 when the Chinese Communist Party (ССР) declared the nation the People's Republic of China, it had assumed Soviet pseudo-science, namely neo-Lamarckian and antiMendelian Lysenkoism, which led to intense propaganda campaigns that victimized intellectuals and natural scientists. Not until the 1956 Double Hundred Campaign had China engaging in meaningful exploration into modern genetics with advancements of Morgan. The CCP encouraged discussions on the impact of Lysenkoism which cultivated guidelines to move science forward. However, Mao ended the campaign by asserting the Anti-Rightist Movement (1957) that reinstated the persecution of intellectuals, for he believed they did not contribute to his socialist ethos of the working people. The Great Leap Forward (1958-1959), an idealist and unrealistic attempt to rapidly industrialize the nation, and the Cultural Revolution (1966-1976), a grand attempt to rid China of the "technological elite," extended China's lost years to a staggering two decades. Post-Mao China rapidly revived its science and technology frontier with specialized sciences: agricultural biotechnology, major genomic ventures, modernizing Traditional Chinese Medicine, and stem-cell research. Major revisions to the country's patent laws increased international interest in China's resources. However, bioethical and technical standards still need to be implemented and locally and nationally monitored if China's scientific advances are to be globally accepted and commercialized.
\end{abstract}

Keywords: history, stem cell, bioethics, agriculture, intellectual property, Lysenkoism

Abbreviations: CCP: Chinese Communist Party; PRC: People's Republic of China; CAS: Chinese Academy of Sciences; NNSF: National Natural Science Foundation; CNCBD: China National Center for Biotechnology Development; HGP: Human Genome Project; MoST: Ministry of Science and Technology; BAC: bacterial artificial chromosome; HB: Hepatitis B; TCM: Traditional Chinese Medicine; CATCM: China Academy for Traditional Chinese Medicine; ES: embryonic stem; MPH: Ministry of Public Health; GMO: genetically modified organism; UCSD: University of California, San Diego; CQMHTIO: Chongqing Municipality High-Technology In-

Material published as part of this publication, either on-line or in print, is copyrighted by the Informing Science Institute. Permission to make digital or paper copy of part or all of these works for personal or classroom use is granted without fee provided that the copies are not made or distributed for profit or commercial advantage AND that copies 1 ) bear this notice in full and 2) give the full citation on the first page. It is permissible to abstract these works so long as credit is given. To copy in all other cases or to republish or to post on a server or to redistribute to lists requires specific permission and payment of a fee. Contact Publisher@InformingScience.org to request redistribution permission. dustrialization Office.

\section{Introduction}

China has been a pioneer in science, discovery, and invention since its early history. In the $6^{\text {th }}$ century BC, Chinese farmers were using a form of agricultural row cultivation and intensive hoeing that was not practiced in Europe until the $18^{\text {th }}$ century. While Dr. William 
Harvey is often credited with discovering the circulatory nature of the human blood system in 1628 , indisputable and abundant textual evidence from the $2^{\text {nd }}$ century demonstrates China's extensive knowledge on this subject (Temple, 1986). China has utilized traditional forms of manipulating living organisms - agricultural biotechnology - including grain cultivation, soy sauce and vinegar production, and bacterial maceration, for centuries.

Despite these achievements, China has failed to undergo the biotechnology revolution experienced in the West during the twentieth century. Republican China (1912-1949) did make a significant effort to achieve scientific prominence, including establishing the Central Academy of Sciences in 1928. However, the Chinese Communist Party's (CCP) indiscriminate acceptance of Soviet pseudo-science, namely anti-Mendelian Lysenkoism, led to intense propaganda campaigns that victimized intellectuals and natural scientists who spoke out against the Party or practiced Mendel-Morgan science.

After years of anti-Mendelian Soviet pseudoscience and decades of anti-intellectual propaganda and persecution, China's biotechnology industry was undeveloped, even backwards. In the postMao era, China instituted a novel modernization and high-technology plan to redress these problems with national science and technological advancement. Deng Xiaoping was instrumental in conveying the idea to the Chinese people that science and technology were key to generating economic wealth and improving the country's international reputation. He instituted many of the biotechnical programs in the universities and medical and agricultural institutes that are responsible for China's well-known achievements in the field today.

This article traces the emergence of modern biotechnology in the People's Republic of China, particularly in the agricultural, genomic, and stem-cell sciences and traditional Chinese medicine. The paper begins with a review of the significant events in biology and genetics education and research in China's modern history. The future directions of the biotechnology industry in the country, such as transparent and peer-reviewed funding mechanisms, bioethical and biosafety standards with proper enforcement, and international collaboration in education and multi-faceted sciences, are also discussed.

\section{History of Science \& Technology in China (1911-2005)}

The collapse of the Chinese monarchial system with the toppling of the Qing dynasty in 1911 marked a turning point in China's science policies. The new Republic of China, under the guidance of the revolutionary leader Dr. Sun Yat-Sen, established local, regional, and national scientific societies and scholarly journals, reinstated study abroad education programs, and founded higher education science departments in evolution, population genetics, and the life sciences. Realizing that science and technology were key to China's economic and political stability and development, the central government actively fostered and protected the fledgling scientific community. The founding of the Central Academy of Sciences (Academia Sinica) in 1928 characterized the culmination of modern Chinese scientific exploration. In addition, the China Science Service was published in cooperation with the US Department of State to educate and inform Chinese scientists about important scientific developments in the West (Fairbank, 1976). In fact, Chinese science often replicated the West.

\section{Sino-Soviet Scientific Philosophy (1949-1956)}

After the defeat of the Nationalists by the CCP in the 1949 Civil War, the People's Republic of China (PRC) uniformly adopted the prevailing Soviet pseudo-scientific philosophical doctrines and theories of the day, particularly those postulated by Lysenko and Michurin. Ukrainian agronomist Trofim Lysenko (1898-1976) condemned the work of Gregor Mendel (1822-1884), 
August Weismann (1834-1914), and Thomas Morgan (1866-1945) because their theories contradicted Marxist doctrine. His anti-Mendelian theories held that acquired traits could be inherited, a notion that was not based on statistical research, a field that Lysenko detested. [This notion was originally proposed by French naturalist Jean-Baptiste Lamarck and later advocated by Soviet scientist Ivan Michurin (1855-1935).] Lysenko dismissed "genes" and "chromosomes" as mere figments of "bourgeois" and "reactionary" idealism. His views found favor with Soviet dictator Joseph Stalin, and he was made President of the Lenin Academy of Agricultural Sciences (1938) and Director of the Department of Genetics at the USSR Academy of Science (1940). [The American pioneering geneticist and socialist Hermann Muller advocated Mendelian genetics, eventually proposing to Joseph Stalin that the Soviet Union establish a eugenics program involving artificial insemination ((Glad, 2003)). Muller's Soviet career ended when he compared Lysenko's neo-Lamarckian thinking to alchemy and astrology in his 1936 address to the Soviet Academy of Agricultural Sciences. A decade later, Muller was awarded the Nobel Prize in Physiology/Medicine for his discovery of x-ray irradiation-induced mutations.]

Genetics in the Soviet Union and Communist China was governed by ideology rather than systematic research and experimentation. Simply put, science was relegated to being a tool of dogma. The Lysenko and Michurin theories, collectively termed "creative Darwinism," severely hindered progress in genetics and molecular biology in the Soviet Union and China. Communist doctrine held that social rather than genetic etiologies were responsible for human inequality. Lysenko's research focused on manipulating an organism's environment to induce a phenotypic alteration that could be inherited in its offspring. His findings led him to extrapolate that the creation of a socialist environment would dictate future human success as their achievements were passed to succeeding generations.

Most Chinese biologists supported orthodox genetics in the 1940s, and few had worked in the liberated areas of North China and Yan'an, the de facto capital of the CCP during the SinoJapanese War (Peishan, 1988). The scientists in these areas were not Western-educated, and they subsequently accepted the major tenets of Lysenkoism without much opposition. The Central Academy of Sciences and two other academies formed the Chinese Academy of Sciences (CAS) in November 1948, standing as the country's highest academic and research institution. Lysenko's 1948 report to the Lenin Academy of Agricultural Sciences, The Situation of Biological Science, was translated into Chinese in 1949 and became a mandatory text for biology departments in higher education institutions (Peishan, 1988). The work attacked and rejected Darwin's theories, particularly gradual evolution, natural selection, and "definite-indefinite" variations. Most Chinese biology texts during this period were translations of Soviet works that contained some additional Chinese cultural and environmental subject material.

Lysenkoism and Michurian biology was adopted as the official party science doctrine in late 1949 (CCP, 1952). Intellectuals and scholars that continued to practice the Mendel-Morganian life sciences were persecuted. Ultimately, under intense pressure to conform, many scientists stopped pursuing such research or switched fields. For example, Dr. Tan Jiazhen, a PhD student of Morgan at the California Institute of Technology and now considered the "Father of China's Genetics," stopped teaching genetics and focused on evolution (particularly paleontology and evolutionary mechanisms), and his infamous Drosophila population studies (Schneider, 2003).

\section{Double Hundred Campaign (1956-1957)}

Although scientists were often unable to reproduce Lysenko's "experiments," his ideology dominated scientific inquiry in the PRC until Sino-Soviet tensions rose in 1956. In a "secret speech" at the $20^{\text {th }}$ Congress of the Communist Party of the Soviet Union, Nakita Khrushchev denounced Stalin as a brutal despot and accused him a several crimes (Peishan, 1988). Khrushchev also supported the production of hybrid-corn seeds, a practice that had been banned in the Soviet Union 
until 1952 and remained forbidden in China (Schneider, 2003). Finally, Lysenko stepped down as President of the Lenin Academy of Agricultural Sciences in April 1956 after hundred of petitioners requested his removal (Hossfeld \& Olsson, 2002).

Chinese representatives at the Congress learned of Khrushchev's speech and reported it to Beijing. Li Zhisui, Mao Zedong's personal physician, has stated that Mao considered Khrushchev "unreliable," and that he would never forgive the attack on Stalin. In fact, Mao believed that the Soviets wanted to "control China" (Garver, 2003). These dramatic changes forced the CCP to evaluate its once uncritical acceptance of transplanted Soviet scientific ideology to "prevent the abuses of Stalin's Russia from being duplicated in China" (MacFarquhar, 1974).

The CCP used the Lysenkoism vs. Mendel-Morganian quandary as the model for future relations between the Party and the Chinese scientific community. In response to Khrushchev's destalinization program, Mao delivered the speech "On the Ten Major Relationships" in April 1956. It spoke of uniting the Chinese people and mobilizing all available resources to build a socialist country in opposition to imperialism and bureaucratic-capitalism (Zedong, 1977). He acknowledged the backwardness of the natural sciences in China and, most importantly, emphasized the need to "learn critically, not blindly" from other countries, neither indiscriminately rejecting nor imitating what is foreign. Soon after, Premier and Foreign Minister Zhou Enlai reported a comprehensive analysis of Mao's speech to the general public in the People’s Daily (E. Zhou, 1957).

Lu Dingyi, Director of the Propaganda Department of the CCP Central Committee, summarized Mao's "Double Hundred - Hundred Flowers, Hundred Schools" policy with the famous slogan: "Let a hundred flowers blossom and a hundred schools of thought contend" (Peishan, 1988). The goal was to strengthen party-intellectual relations through open discussion and criticism. Improving the state's treatment of intellectuals was emphasized rather than granting academic freedoms or individual rights. Lu Dingyi also echoed Mao's call to learn from the objective approaches to education practiced abroad.

Lu Dingyi's pronouncements formed the framework for the Double Hundred Campaign. He initiated discussions among members of the Chinese scientific community in an effort to promote the new policy, eventually leading to the Qingdao Symposium on the genetics dilemma. (Peishan, Qingzhe, Qinghe, \& Shun'e, 1985) The symposium commenced on August 10, 1956 with 130 attendees (50 of whom presented) representing both the Mendel-Morgan and the Lysenko schools. Tong Dizhou (1902-1979), Director of the Department of Biology of the CAS, chaired the opening and closing ceremonies. The main subjects of discussion were heredity, embryology, evolution, and genetics education and research.

The two-week symposium revealed that most Chinese biologists were "shielded" from the biotechnological breakthroughs that had occurred in the West because they were denied access to the relevant literature. However, some were aware of the relatively poor progress of China's scientific community in comparison to Western genetics research. The Morganists shared the results and implications of their experiments in identifying and characterizing genes and RNA. They criticized the CCP for forcing them to abide by Soviet "colonial science" and the government's failure to trust or support the Chinese scientific community (Schneider, 2003). While the Qingdao Symposium inspired similar discussions in other sciences, including physiology, pathology, chemistry, and quantum mechanics, the Double Hundred Campaign lost direction after 1956.

\section{Anti-Rightist Movement (1957)}

The Double Hundred Campaign permitted intellectuals to openly discuss national problems, including Lysenkoism and Michurin biology. However, as a result of this new openness, harsh criticism and complaints were directed against the Party, with some even published in newspapers 
and journals. Simply put, scientists did not want the Party to impose restrictions on their work they believed that the direction and conduct of scientific inquiry was best left to them.

Mao and the CCP did not foresee the massive discontent the Double Hundred Campaign generated. In July 1957, under intense pressure from the CCP, Mao initiated an Anti-Rightist Movement that resulted in the condemnation, imprisonment, and death of many intellectuals. It also marked the start of the "Two Lost Decades," a period that saw no attempt to foster scientific talent or education to further China's national development.

The persecution of intellectuals and their families began just weeks after criticism of state policies and methods was first permitted. Thousands of "rightists," mostly literary intellectuals and some natural scientists, were exiled to rural areas, sent to labor camps, or jailed (Hao, 1997). The backlash was directed at those who directly spoke against the Party or socialism; critics of Lysenkoism were often spared (Peishan, 1988). In five months, over 300,000 people (the "rightists" and their families) were persecuted in some way (Spence, 1990).

\section{Great Leap Forward (1958-1959)}

The Anti-Rightist Movement was followed by an ill-fated socialist program of economic development and independence known as the Great Leap Forward (1958-1959). Mao and the CCP interpreted the Soviet Union's weakening economic situation in the 1950s as an opportunity for China to rapidly industrialize. This involved a massive shift of the country's human resources from agriculture to industry. While the Anti-Rightist Movement sought to suppress intellectuals that opposed absolute control by the Party, the Great Leap Forward planned to end China's reliance on a technological elite. The underlying principle was summarized by Mao's slogan: "The masses must make themselves masters of culture and science" (Meisner, 1999).

Over 100 million peasants were mobilized to construct water-conservation systems while other agricultural tasks were neglected. Some peasants were even sent to the CAS Institute of Agricultural Sciences and, in turn, scientific experts were forced to work on farms (Schneider, 2003). The purpose of this switch was to force the technological elite to "learn from the farmers [and] sum up their invaluable experiences to lead to higher yields" (Schneider, 2003).

Envisioning a true communist society, Mao claimed China would surpass Britain in steel production within 15 years; in reality, production quotas were often aligned to his revolutionary goals. The Great Leap Forward proved to be a total failure - its legacy was economic ruin, widespread famine, environmental degradation, and the collapse of modern and professional specialized scientific research and inquiry in the PRC.

The natural sciences were partially rescued after the Great Leap Forward through Mao's promotion of the "science of the people." Although conflict continued, the country's reliance on high technology and scientific developments necessitated the return of leading economists, central planners, and proponents of professional science to the Party. After Mao resigned as Chairman of the PRC, Liu Shaoqi became his successor.

The CCP Central Committee sponsored a national conference in Canton in 1960 to improve China's poor record of scientific innovation and education. Lu Dingyi restarted the Double Hundred Campaign for specialized fields, including genetics. Dr. Tan Jiazhen (P. Chen, 1962) stated that the Canton Genetics Conference genuinely attempted to rebuild genetics research by reinstituting the principles of the 1956 Qingdao Symposium. As a result, Chinese scientific societies, scholarly journals, and major experiments were briefly revived.

Mao also sought educational reforms known as the Socialist Education Movement (1962-1965) to restore ideological purity and prevent the creation of a technological elite. Under this new system, schools adopted work-study programs that required students to participate in manual labor activi- 
ties. This policy generated conflict within the Party, particularly between PRC Chairman Liu Shaoqi and CCP General Secretary Deng Xiaoping. While the controversy over the Social Education Movement and the devastating consequences of the Cultural Revolution caused Liu's downfall, Deng was ultimately credited with reviving China.

\section{Cultural Revolution (1966-1976)}

Many studies have chronicled the devastating events of the Cultural Revolution (MacFarquhar, 1974). Suffice it to say, the Cultural Revolution had severe negative consequences for the Chinese science community. On June 1, 1966, the People's Daily announced that all "imperialists" and "intellectuals" must be purged from the country. This "Cultural Revolution" was intended to rescue China from the treacherous "rightists" who were seeking a "bourgeois restoration." In practice, intellectuals and their families were subjected to humiliation, violence, and even killed. Some chose to escape the cruel persecution by committing suicide. Not even the communist leadership was spared: Liu Shaoqi was imprisoned, eventually dying in 1969 from starvation and poor sanitation; Deng Xiaoping was forced to perform manual labor in an engine factory.

The Cultural Revolution halted educational and scientific progress in China through the closure of all schools and research institutions. The CAS was disbanded in 1967, and the State Science and Technology Commission was abolished in 1969, with the members of education faculties "sent down" to rural areas to work as manual laborers (Schneider, 2003). Dr. Tan Jiazhen noted that the only positive aspect of the Cultural Revolution was that "some old Lysenkoites were sent down with the rest of the biologists, and finally got a taste of their own medicine" (Schneider, 2003). The revolutionary committee also relocated the Beijing Agricultural University to the countryside because they believed that agricultural sciences should not be taught in a city. The former university campus was subsequently transformed into barracks and offices for the People's Liberation Army.

In 1976, the end of the Cultural Revolution was marked by Chairman Mao's death and the arrest of political radicals instrumental to extending the revolution. However, severe damage had been done to Chinese science by that time. There were three principle consequences: First, students who had been denied access to educational institutions became a "lost generation." Second, scientists were ignorant of scientific advances because they had been barred from laboratories and unable to read the literature. Finally, the understanding and practice of science had been completely removed from the working class, creating a new and dangerous bourgeoisie. Facing these problems, the post-Mao leadership engaged in reformist campaign to restore the capabilities and standing of the scientific community.

\section{Science Reformation Post-Cultural Revolution (1976-2005)}

After two decades of gross interruptions - the Anti-Rightist Movement, the Great Leap Forward, and the Cultural Revolution - science in China was slowly put on a permanent pathway of reform. In the post-1976 era, political leaders like Deng Xiaoping actively implemented modernization, globalization, and high-technology policies and programs in an attempt to revive scientific thought, systematic experimentation, and biotechnology research in the country. Party leaders even condemned the attacks on science and scientists that occurred during the Cultural Revolution. Deng realized that scientific research and technological development, as well as interaction with the international academic community, had to be pursued in the long-term. Remarkably, prominent intellectuals such as Dr. Tan Jiazhen joined the CCP in the hope of influencing the reform process and improving conditions in the nation (Saich, 1989).

Deng's Four Modernization plan called for a national movement in science and technology, agriculture, national defense, and industry (Deng, 1977). Mao’s focus on class struggle and self- 
reliance was disregarded in favor of individuals using their hands or brains to build a powerful socialist state. At the National Science Conference on March 18 1978, Deng stated: "Without the rapid development of science and technology, there can be no rapid development of the country" (Deng, 1978).

Deng Xiaoping revitalized the spirit of the people, instilling a sense of unity between the peasantry (i.e. farmers) and intellectuals (i.e. academicians, artists, scholars, scientists). It was also acknowledged that a comprehensive survey of China's scientific output and higher education resources was necessary. The results were presented in the State Science and Technology Commission’s 1986 "Sci-Tech White Paper" (Commission, 1986). In addition, the newly formed Beijing University Center for the Study of Science and Society addressed China's history of intellectual persecution through an intensive examination of the Double Hundred Campaign and the events that followed (Schneider, 2003). Lysenkoism was used a cautionary example of the danger of permitting politics and ideology to violate intellectual independence and integrity.

The CAS research institutes also restarted their experiments and education programs during this period. In 1982, the CAS created the Science and Technology Fund to support research in the universities through competitive grants, which had largely been absent since 1956. In the first three years, 120.33 million yuan was provided to conduct 2,433 approved projects. In 1986, the Fund became the National Natural Science Foundation (NNSF), which was independent of the CAS and funded directly by the Ministry of Finance. The Frontiers in High Technology Program, emphasizing the potential of the applied sciences, was eventually replaced by the larger 863 Program

The China National Center for Biotechnology Development (CNCBD) was established in 1983 to manage and distribute funds for biotechnology research in agriculture, food processing, and pharmaceutical manufacturing. The CNCBD also provided consultative and promotional services for China's burgeoning biotechnology industry. In 1986, Deng Xiaoping ordered the formation of the High Technology Research and Development (863) Program in response to international strategic programs using novel sophisticated technologies. With a total budget of 10 billion yuan, the program was tasked with providing 15 years of research and development promotion (19862000). To reduce the science and technology gap between China and other nations, the 863 Program provided millions of yuan per year for applied agriculture, medicine, and protein engineering projects. Although the grant system was peer-reviewed, there was a "complex negotiation process" involving various government committees and centers (Hamer \& Kung, 1989).

The CAS and the US National Academy of Sciences jointly sponsored Biotechnology in China, an evaluation of China's state-of-the-field analysis between 1986 to 1989 (Hamer \& Kung, 1989). The study noted that the allocation of biotechnology research funding was decentralized, with only $1.7 \%$ of funding in 1989 provided to applicants that directly requested financial backing. While the study stated that China's biotechnology sector improved significantly in the preceding decade, it was still far behind the developed nations.

\section{China's Specialized Biotechnology}

In 1973, Stanford medical professor Stanley Cohen and UCSF biochemist Herbet Boyer made landmark discoveries in modern biotechnology: Cohen found that plasmids, or circular DNA, can be cloned and propagated in E. coli bacteria, while Boyer identified the restriction enzyme EcoRI that had DNA cleaving activity. Together, these two discoveries could be used to engineer cellular DNA (genetic engineering). Scientists eventually synthesized somatostatin in bacteria, the first human protein made using recombinant technology.

Despite the obvious importance of these new methodological discoveries, several factors delayed the transmission of recombinant DNA technology to China's scientific institutions until the early 
1980s. First, the Cultural Revolution resulted in a deficit of trained personnel who were capable of performing such complicated experiments. Second, China lacked the proper facilities and reagents to proceed with recombinant experimentation. Finally, financial support was limited to scarce foreign sources that relied on scientists willing to engage in such biotechnology work. In later years, the 863 High Technology Program and the National Basic Sciences (973) Initiative, with a total budget of 2.5 billion yuan (1997-2002), were willing to provide substantial funding for such research. The CAS, State Science and Technology Commission, and other Chinese academies eventually reversed China's shortfalls by launching rapid exploration into the new frontier of modern biotechnology.

\section{Agricultural Biotechnology}

The forces driving China's agricultural biotechnology research are food security (Zhang, 1999), scientific progression, and health. Early biotechnology developments in China focused on cell engineering and tissue culture, and emphasized work on plants such as rice, wheat, and cotton. However, funding from the 863 Program made the development and utilization of transgenic techniques common. Chinese research institutions, including the CAS and the Chinese Academy for Agricultural Sciences, prioritized plant biotechnology research funding for cotton, rice, wheat, maize, soybean, potato, rapeseed, cabbage, and tomato. Genetic engineering to achieve insect resistance, disease resistance, stress tolerance, quality improvement, and herbicidal resistance were sought by Chinese agricultural biotechnologists in the mid-1980s. As a result, China rapidly became a global leader in the field.

China's success is amply illustrated by its development of the enormously successful Bacillus thuringiensis (Bt) resistant cotton. The breakthrough occurred in the search for alternatives to using pesticides to control common insects that were decimating certain types of agriculture. For example, pesticide expenditures had skyrocketed in an effort to protect cotton production from the bollworm. Moreover, the widespread use of pesticides jeopardized farmers' health and limited biodiversity in the cotton fields. Using the pollen-tube pathway transformation technique, China's scientists transferred a modified Bt gene into major cotton cultivars. After greenhouse studies, mutation and lineage analyses, and biosafety inquiries, the genetically modified (GM) crop was approved in 1997 for commercial distribution (Xu \& Bai, 2002). Today, China's Bt cotton is the world's most prevalent transgenic crop for small farmers. Chinese scientists have since modified hundreds of plant varieties, although very few have been approved for commercial use. A Chinese university greenhouse is shown in Figure 1.

In the 1990s, China's agrobiologists transferred techniques learned while studying in the West to the domestic biotechnology industry (e.g., marker-assisted breeding, selection, and introgression, and chimeraplasty). Subsequently, many novel transformation methodologies using Agrobacterium and gene-gun particle bombardment technology have been used to study transgene inheritance (Yin, Plader, \& Malepszy, 2004), bacterial blight resistance in transgenic rice (Zhai et al., 2004), cotton fiber quality (D. M. Li et al., 2003; X. Li, Wang, Zhao, \& Dutt, 2004), and aphid resistance in transgenic tobacco (J. Yao et al., 2003; J. H. Yao et al., 2003).

China is projected to continue to develop its specialized molecular plant sciences and has even recently ventured into oral immunization research, or "edible vaccinations." China's plant molecular biologists realize that crops can be genetically modified to produce disease-like, yet harmless, antigens that can stimulate humoral immunity after ingestion. Most plant-based antigen protein expression system studies are currently in the experimental animal testing phase, including hepatitis B immunity via transgenic cherry tomatoes (Y. Gao et al., 2003) and rotaviral immunity using transgenic potatoes (Wu et al., 2003). Edible vaccines would be cheap to produce, easy to transport, and act as an ideal vector for resistance to human pathogens. However, problems with oral immunization include variance in production causing irregular antigen concentration, the 


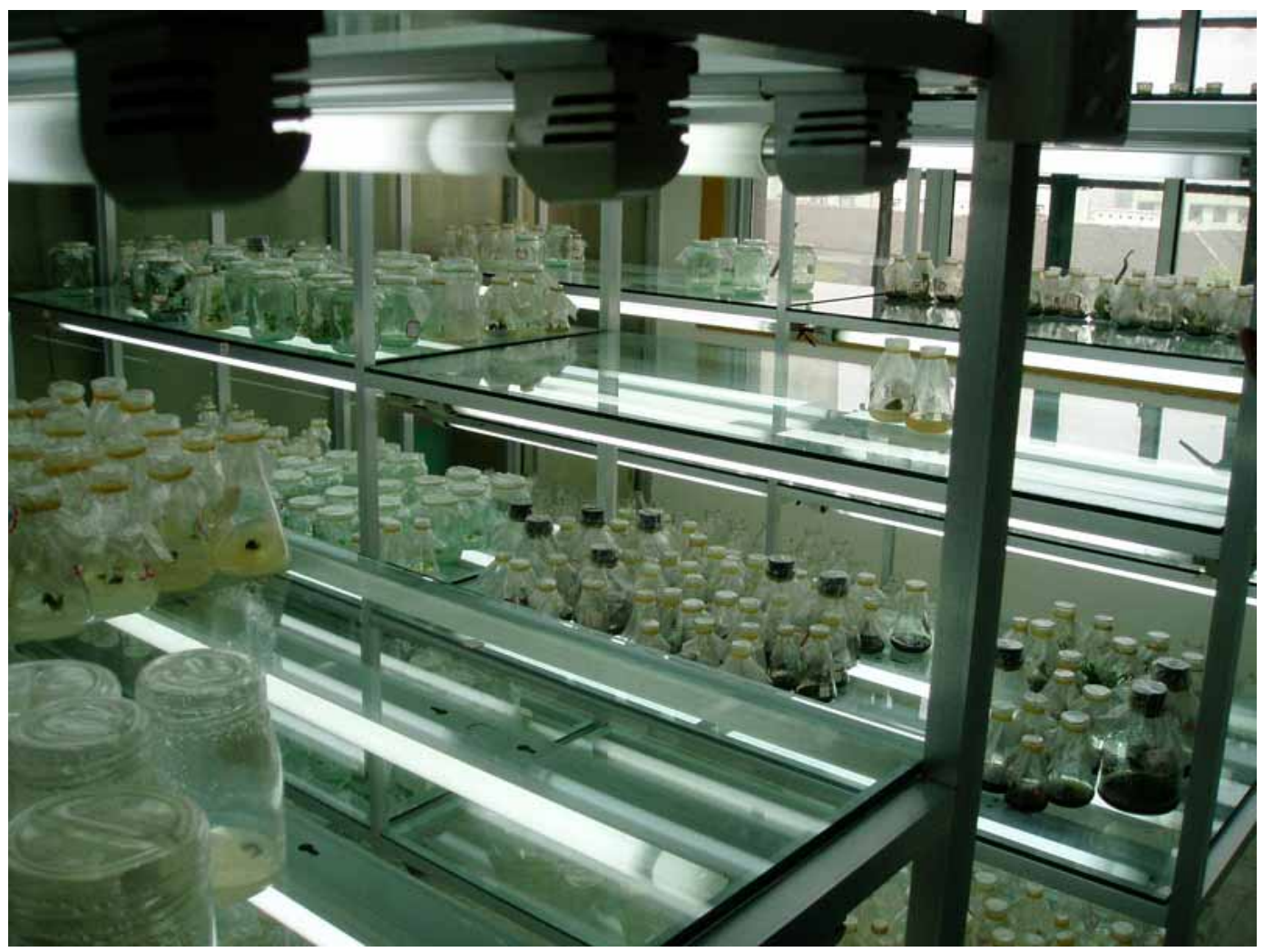

Figure 1. An example of a greenhouse facility in China.

potential for accidental ingestions, and the inability to mediate essential post-translational modifications that trigger the immunity response.

China now possesses the largest plant biotechnology capacity outside of North America (Huang, Rozelle, Pray, \& Wang, 2002), with over 100,000 research staff in well-equip laboratories as shown in Figure 2. A substantial pool of well-trained scientists, relatively inexpensive research experimentation, and access to a variety of plant germplasm and cell lines provides China with many advantages compared to other countries. Agricultural research and development in China is likely pursue many potential transgenesis paths, such as metabolic engineering and the manipulation of plant biochemistry for the production of non-protein based products (e.g., antipyretic quinine, unsaturated fatty acids, pigments, and biodegradable plastics).

\section{Major Genomic Projects}

China has made a major leap forward by collaborating with renowned universities around the world on the most ambitious and intensive genome study, the Human Genome Project (HGP). Sponsored by the US Department of Education and the National Institute of Health, the HGP began in 1988 with the objective of developing the methodology to successfully sequence the entire human genetic code. In 1997, the newly established National Human Genome Research Institute noted that recently developed methodologies would be essential to sequencing human DNA.

Despite skepticism about the ability of a developing country to effectively participate in the HGP, China joined the International Human Genome Sequencing Consortium in 1998 to work alongside France, Germany, Great Britain, Japan, and the United States. China’s State Science and Technology Commission became the Ministry of Science and Technology (MoST) the same year. The MoST established two institutions under the direction of the CAS to spearhead China's role 


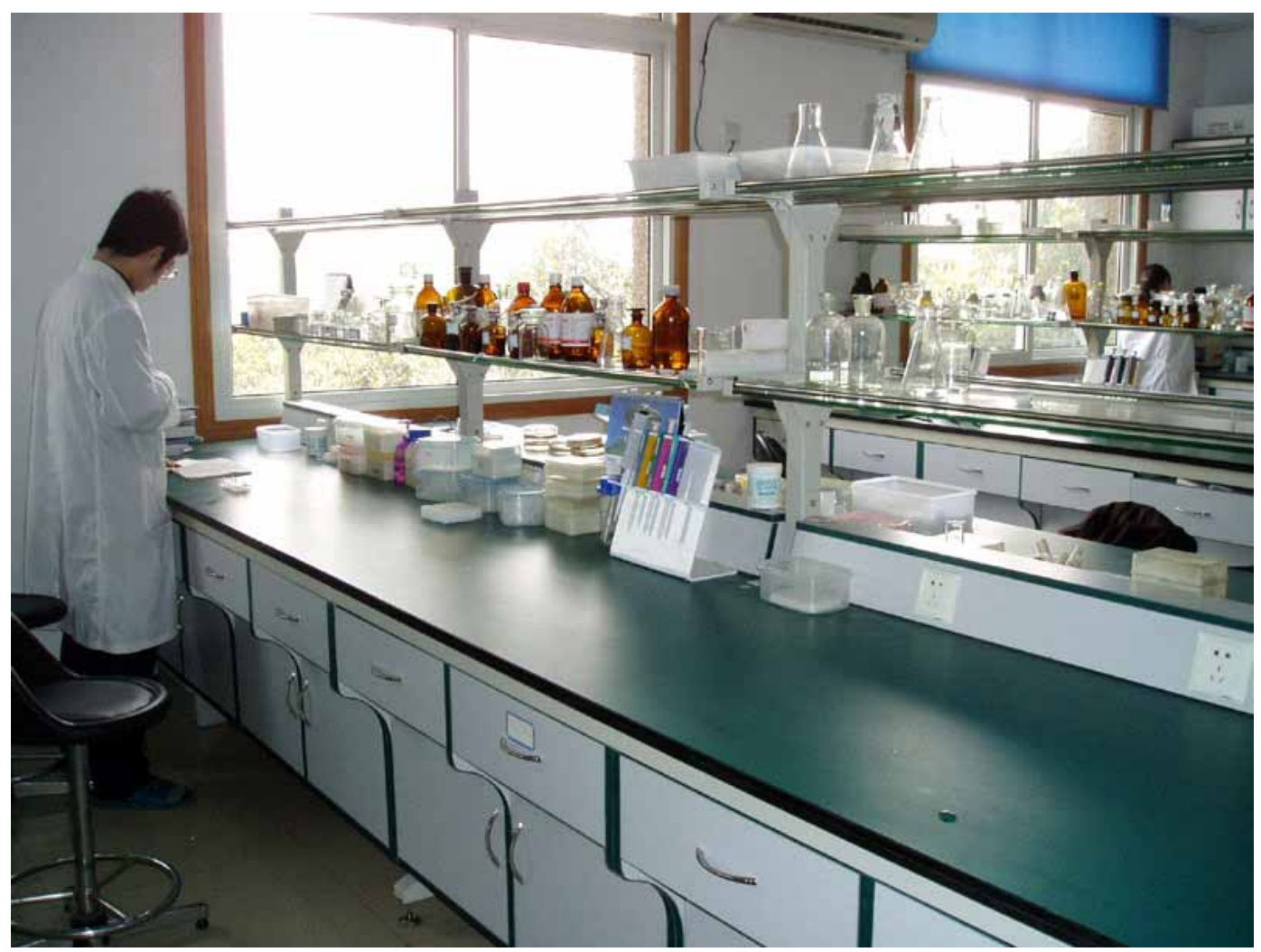

Figure 2. An example of a research laboratory in China.

in the project: the Beijing and Shanghai Human Genome Centers. Zhu Chen, then Vice President of the Chinese Academy of Sciences, and Prof. Boqin Qiang, an academician of the CAS, were appointed to run the Shanghai and Beijing divisions, respectively. The Beijing Center was better equipped to perform high-throughout and quantity genome sequencing and bioinformatics analysis, while the Shanghai Center was more oriented to functional medical genomics. A third institution, the Beijing Genome Center/Bioinformatics Center, was established later.

In 2001, the International Human Genome Sequencing Consortium published their landmark construction of the whole-genome bacterial artificial chromosome (BAC) map with limited annotations (McPherson et al., 2001). China contributed to $1 \%$ of the published sequence, particularly the short-arm of chromosome 3, labeled the "Beijing region."

Chinese institutions engaged in another major genomic venture in 2003, the International HapMap Project, which is trying to determine shared patterns of DNA variation in the human genome from populations with ancestry from Africa (Nigeria), Asia (Japan and China), and Europe (Utah residents of northern or western European decent) (Consortium, 2003). The Beijing and Shanghai Human Genome Centers, University of Hong Kong, Hong Kong University of Science and Technology, and the Chinese University of Hong Kong will haplotype and screen an estimated 10\% of the human genome on chromosomes 3, 8p, and 21. Beijing Normal University and Beijing Genomics Institute will aid in community engagement and procuring samples, respectively.

China is also participating in the ten-country International Rice Genome Sequencing Project that is promoting the development of rice and cereal genomics. Remarkably, the Beijing National Genome Center published the draft sequence of the rice genome Oryza sativa - the most important crop for human consumption -in Science (Yu et al., 2002). The Beijing Center had succeeded at 
the task after only a few months work, while competitors who had dedicated intensive amounts of time and effort failed to produce large-scale published genomic data.

China will continue to generate sequence data on human, rice, and experimental organism genomes, and enrich the annotation profiles of the identified genes. In addition, Chinese scientists sponsored by the MoST are proposing a Human Proteome Project and the Human Liver Proteome Project (H. Jia \& Louet, 2004). The latter project is in direct response to the Hepatitis B (HB) pandemic that has infected nearly 170 million people in China (Sun, Ming, Zhu, \& Lu, 2002). The nationwide HB vaccination campaign and the universal immunization of newborns initiated by the Ministry of Public Health and World Health Organization has decreased the rate of new infections; however, the Human Liver Proteome Project could reveal new diagnostic and therapeutic options for current suffers.

Profiling, identifying, and creating anti-bodies for the entire human proteome is a greater feat than the HGP, as proteins are subject to multiple structure levels, various expression and interaction pathways, and a host of possible modifications. Thus, China is rapidly becoming a leading nation in the quest to understand basic human biology and the mechanisms of disorders.

\section{Modernizing Traditional Chinese Medicine}

China has a long - even ancient - history of using herbological and acupuncture intervention to treat a variety of medical disorders. Theories of $Q i$, a neuroendocrinological regulatory substance, state that it is the life and vital force of the body. Qi circulates the body in a systemic pattern, stimulating and regulating organ systems. Interruptions of flow induce disease by way of $Q i$ antagonists (e.g., physical or emotional trauma, radiation, thermo instability, nutritional imbalance, environmental pollutions, or intoxicants). Health is ultimately defined as equilibrium established and controlled by the Yin/Yang theory of opposites and interdependent processes and systems.

Mao understood the power of Traditional Chinese Medicine (TCM), avidly supporting its widespread use on the rural masses after the 1949 CCP victory. He referred to TCM as the nation's "treasurehouse," and urged the Chinese people to "raise its standards" (Unschuld, 1985). In 1955, the China Academy for Traditional Chinese Medicine (CATCM) was established in Beijing as the center of TCM research, healthcare, and academics in the country. The CATCM was tasked with developing mass production methods, creating viable strains of herbs, and offering quality control policies.

The Institute of Chinese Materia Medica (a division of the CATCM) had been responsible for performing basic research into herbological compounds. While the staff lacked adequate training into biochemical experimentation, they assisted in a discovery that benefited the international community. During the Cultural Revolution, Mao chose to spare a group of scientists in the Materia Medica in a bold attempt to find a domestic compound with anti-malarial properties, or even a cure. Mao recognized the destructive impact of malaria on the country, and perhaps he also realized that such a discovery would generate enormous respect for TCM. After an intensive search through thousands of ancient medicinal recipes, the scientists isolated artemisinin from qinghao (Artemisia annua, sweet wormwood). Ancient literature noted that the herb produced thermostability when administered to patients with fevers. The researchers found that artemisinin could combat resistant strains of the malaria parasite (H. H. Chen, Zhou, \& Fang, 2003; Efferth, Dunstan, Sauerbrey, Miyachi, \& Chitambar, 2001) and recent work suggests it has anti-cancer properties as well. Derivatives of artemisinin are the most rapid acting of the known anti-malarial agents, and they have been administered to more than one million patients around the world (White, 1996).

Chinese biotechnology companies are also developing computerized instrumentation that can provide TCM doctors with greater diagnostic capabilities. For example, Chongqing Tianhai 
Medical Equipment Inc. has developed a tongue reader with an integrated CCD video system and image analysis software to detect discoloration and textural changes (useful for diagnosing conditions like psoriasis, which produce a crimson tongue with a yellow coating; see Figure 3 for an image of this bioinstrument).

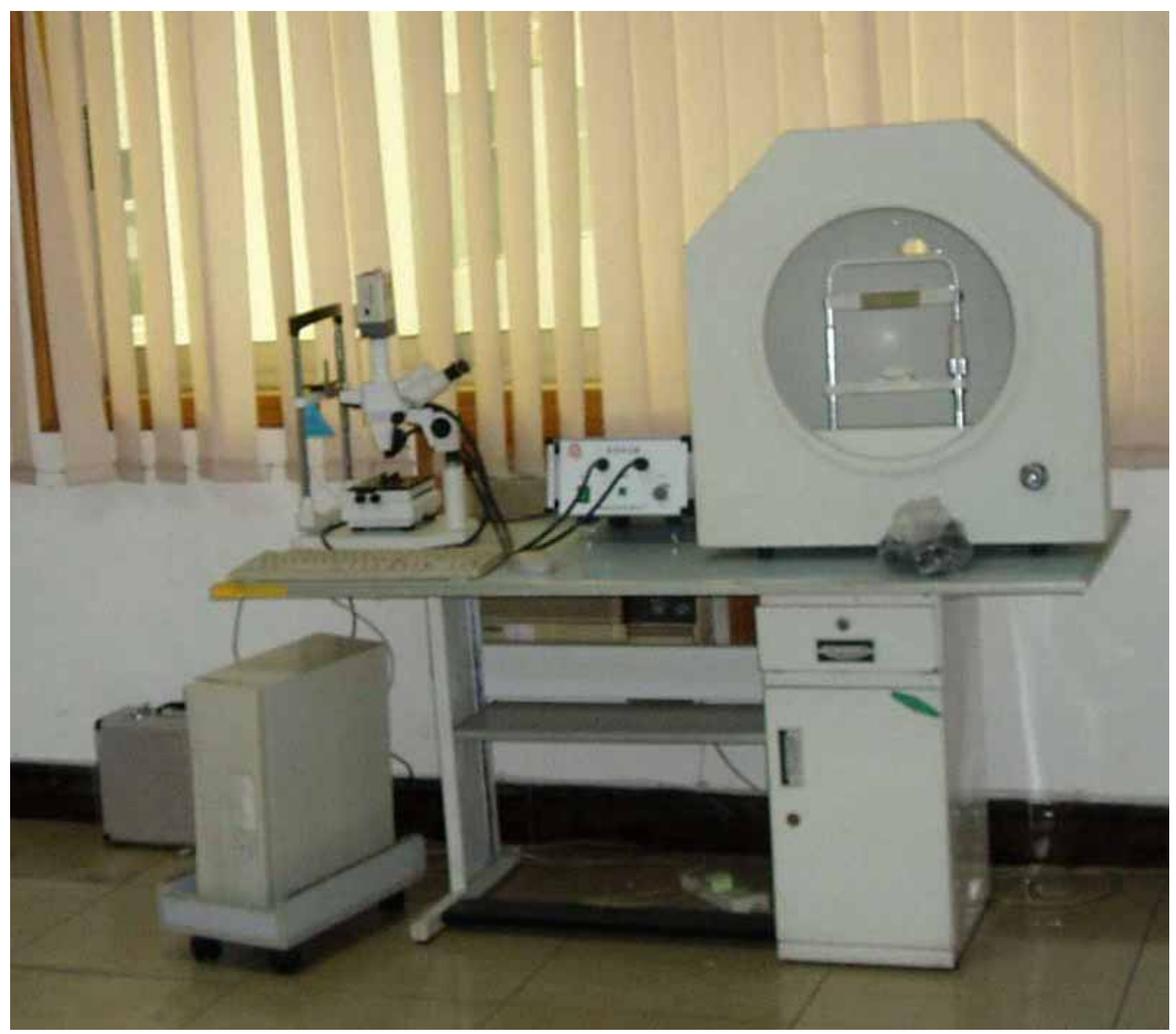

Figure 3. Instrumentation used by TCM doctors to observe facial and oral features for clinical diagnosis.

Deng Xiaoping's modernization program called for research into the biochemical mechanisms of herbal compounds and extended trade with the outside world. Other TCM compounds with potential clinical effectiveness have been noted for diabetes (W. Jia, Gao, \& Tang, 2003), improper blood circulation (F. W. Li et al., 2001), and hypertension (C. Zhou, Yu, Li, \& Tian, 2001). However, the lack of acceptance of TCM by the Western medical and scientific community remains a central concern of TCM health professionals and researchers.

\section{Stem-Cell Research \& Regenerative Medicine}

China's 1979 One-Child Policy will eventually create a disproportionately elderly population that receives an uneven provision of support, particularly in poorly developed rural areas (Joseph \& Phillips, 1999). Chinese scientists are exploring stem cell research, therapeutic developments, and regenerative medicines as potential solutions to the aging crisis. In the United States and Germany, stem cell research was proceeding rapidly until government sanctions prohibited federal funding for human embryonic stem (ES) cell research conducted after August 2001 and January 
2002, respectively (Gershon, 2003). In contrast, China, the United Kingdom, Australia, India, Israel, Singapore, and Sweden have established more liberal research policies.

All tissues and cells of the embryo and adult organism trace their origin to the pluripotent cells with developmental plasticity of the early mammalian embryo (Hogan, Beddington, Costantini, \& Lacy, 1994). Tissue defects, including cellular loss and/or function, can be treated with stem cell regenerative therapy. Contending with the HBV epidemic made China a pioneer in the advancement of allogeneic hematopoietic stem cell transplantation for the prevention or deferral of hepatitis (Lau et al., 2002; Ma et al., 2004). As a result of high incidence of insulin resistance in China, researchers at the Third Military Medical University in Chongqing are investigating the plasticity and transdifferentiation potential of adult pancreatic ductal cells as potential stem cells into insulin producing islet cells with positive findings (Yao, Qin, Liu, Chen, \& Zhou, 2004).

The Shanghai Second Medical University has demonstrated that scientists may be able to bypass human embryos for harvesting human ES cells by nuclear fusion of the human somatic nuclei from skin cells into enucleated rabbit eggs (Y. Chen et al., 2003). The procedure may help avoid immune incompatibility for future cell therapies. After electrofusion and cell culture, the reconstituted cell undergoes normal embryological development. The scientists collected ES cells from an embryo at blastocyst stage, and found that the somatic cell nuclear transfer procedure generated ES cells that retained traits similar to those of conventional human ES cells. Most importantly, the cells could undergo multi-lineage cellular differentiation; however, self-renewal capabilities were not addressed. This study demonstrates the progress of China's cellular engineering technology, but also hints at a lack of ethical regulation in the biomedical sciences.

\section{Concerns for China}

Scientific discovery and technological development has occurred rapidly in China in the past twenty years, with certain applied science fields now on par with the West. Concentrated funding programs from the MoST have boosted genomic exploration and stem cell research. Areas of particular national concern, such as food insecurity, hepatitis B, and a disproportionately aging population, have led China to develop specialized forms of science. However, China must pursue active reforms and intensive development in other sectors if it is to achieve a long-term reputation for innovation. First, China's bioethics system fails to meet accepted international standards. Second, grant funding is highly specialized and review policies are ambiguous. Finally, China must increase its willingness to seek international participation and collaboration in scientific endeavors that require expertise in many sectors (e.g. stem cell therapies).

\section{Bioethics, Biosafety, \& Regulation}

Policy makers in China are beginning to understand the positive implications of developing and implementing ethical and technical standards. Recent biotechnological regulations indicate progression towards the fostering of an ethical scientific and medical community; this is not surprising given China's membership in the World Trade Organization in 2001. Scientists often study abroad and return to China, bringing with them the bioethical standards of their post-doctoral institution. Nevertheless, ethical science is certainly not practiced by all scientists in China. In fact, bioethical standards are often maintained only because violations can prevent publication in prominent Western journals or halt participation in international research projects or pharmaceutical marketing.

Sex selection has been practiced in China for long time. Modern technology (e.g., amniocentesis, ultrasound, and chorionic villi sampling) has empowered couples seeking to manage sex selection and family size. In response, the Maternal and Infant Health Care Law of 1995 forbade prenatal genetic diagnosis that may lead to sex selection, and demanded full basic health for the entire 
population (Doring, 2003). However, the legislation also permits the use of a highly controversial eugenics statute that facilitates the systematic abortion of offspring with mental diseases. Although the Chinese people believe in individual autonomy, they also hold that autonomy is guided by social needs.

In 1998, the Ministry of Public Health (MPH) formally banned human cloning, with no exception granted for therapeutic cloning (Doring, 2003). In fact, the public showed little opposition to such practices, and China is considered the world's most liberal nation in terms of embryo research. To halt the operation of numerous unlicensed in-vitro fertilization centers that conducted artificial insemination from unknown donors, the MPH implemented further restrictive policies in late 2001. China has now instituted tightly controlled systems of assisted reproduction and spermbank licensing to halt substandard operations.

Many Chinese research institutions have yet to implement or enforce ethical standards, particularly governing the humane treatment of animals. The China Wildlife Conservation Association and International Fund for Animal Welfare have unsuccessfully lobbied the Chinese government to institute laws protecting animal welfare. The Beijing Municipal Government considered a draft proposal for four days in 2004, but eventually rejected it without providing a reason (Xinhuanet, 2004). Given that more than 100 countries have instituted animal protection laws, including many developing countries in Africa, China is lagging significantly behind the international norm.

As genetically modified organisms (GMOs), plant medicines, and embryological manipulation become increasingly common, ethical and biosafety questions are naturally raised and must be addressed. The potential ecological risks associated with transgene escape through gene flow or cross-pollination has already been noted. For instance, transgenes may propagate within weedy or wild plant varieties through sexual reproduction or asexual vegetative propagation. Traits such as antibiotic, pesticide, and temperature resistance may significantly enhance the ecological fitness of weedy and wild populations or destroy endangered species. Risks from GM crops should be closely monitored and measured. Regulatory agencies, as established in the US (e.g., Food and Drug Administration and Environmental Protection Agency) perform monitoring, approval, and assessment tasks, a practice that China must adopt.

Chinese scientists must realize that their studies may not be published, their access to foreign funding restricted, international collaboration halted, or the nation's reputation jeopardized if legally binding and effective monitoring systems are not established for bioethical research. Furthermore, ignorance of agricultural biosafety could cause the production of transgenic weeds that are resistant to pesticides or cause the extinction of endangered species in local ecosystems.

\section{Patenting Biotechnology}

The Patent Office of the PRC was founded in 1980 as a component of Deng Xiaoping's globalization program. China revised its Patent, Trade Mark, and Copyright Laws in 1992 and 2000, and they are now similar to those in the European Patent Convention. An invention is clearly defined as patentable if it possesses novelty, inventiveness, and industrial applicability. The revisions also made it easier to determine the court jurisdiction of an infringement lawsuit and raised the maximum intellectual property remedies to 500,000 yuan. Genetic technologies rely on main patent protection, while new species of plants and animals fall under special protections.

These new intellectual property protections in coverage and enforcement were established to promote investment in the Chinese market, improve international collaboration, and reward technical innovation. More than 250,000 applications were filed between 1985 and 1999, mostly for Chinese herbal medicines, foodstuffs, and pharmaceuticals (Lui, 2001). Since 2003, China's patent agency has reviewed nearly three million applications, many of which are for new genetic 
engineering techniques and methods for modernizing TCM. As a result of these changes, foreign companies are finally starting to trust China's life science intellectual property systems.

\section{Funding Mechanisms}

There are major problems with China's current funding approval and dispersal mechanisms. The optimal system would be similar to that implemented by the US National Institute of Health, which is characterized by a transparent review process, equitable scoring system, and mandatory reviewer comments for every application.

In some ways, the traditional Chinese work system is responsible for some of the problems in this area. Until the 1960s, the Chinese urban workforce was governed by a "work-unit system" called danwei. The workplace was a relatively regimented and controlled environment, providing the principle means of support for workers, including their room and board. Budgets were allocated to the work-unit rather than to individual scientists, often resulting in redundancy and poor information distribution. While post-Cultural Revolution reforms have reduced the use of danwei, it continues to harm the scientific inquiry. For example, it is still common for a scientist to remain at one institution for their entire career, and this lack of mobility can seriously impede effectiveness. Moreover, the procedure for dismissing government workers remains lengthy and troublesome; it is therefore often avoided by administrators.

While the 863 Program peer-reviewed funding applications for high-technology research, the process involved many different government organizations and the policies were unclear. The 973 National Basic Sciences Initiative made significant improvements to this review procedure; in fact, 15 new projects funded by this program in 2003 were published in Science (Lei, 1998). The remaining concerns that need to be addressed include the artificial inflation of grant budgets to keep the surplus for personal use and the implementation of a transparent and accountable application review process.

\section{Conclusion}

The CCP's blind acceptance of Lysenkoism from 1949 to 1956 was detrimental to the development of the Chinese scientific community and the welfare of the population. Its doctrinaire assertion that genes and chromosomes are mere fabrications of "bourgeois" and "reactionary" idealism has caused untold suffering. How much grain was lost by failing to utilize well-known hybrid crop techniques? How many millions of Chinese people died from starvation as a result? How much did this philosophy prevent or impede China's industrialization, economic progress, and scientific competence?

Modern Chinese history clearly illustrates how social-political philosophies can affect natural sciences and, by extension, the development of an entire society. Mao Zedong's attempt to control science and scientists decimated China's economy and halted technological progress. By actively seeking to repress and eliminate intellectuals and the "technological elite" to achieve a socialist ideal, Mao paralyzed the ability of the country to adapt to the modern world. Deng Xiaoping's effort to regenerate scientific exploration and technological development was an acknowledgement that progress in these fields is the driving force of modernization, whether scientific, economic, military, or agricultural. The establishment of dedicated national biotechnology centers such as the NNSF and CNCBD facilitated the development and organization of important applied science projects in China. Progress was also driven by the Frontiers in High Technology Program, High Technology Research and Development (863) Program, and National Basic Sciences (973) Initiative. In fact, the 873 funding program has allowed China to develop specialized biotechnology sectors that now make it globally competitive. 
Advancements in plant biotechnology, TCM, and embryological biology in application-oriented and fundamental mechanisms will occur rapidly in China over the next five years. Important research in the basic sciences has already occurred, for instance, regulation of smooth muscle contractility (Yang et al., 2002), human Bim proapoptotic activity (J. Z. Chen et al., 2004), novel regulators of NF-kappaB pathways (H. Gao et al., 2004), heterotic effects at the single-locus level (Hua et al., 2003), and bHLH-Zip gene role in human spermatogenesis (Sha et al., 2003).

Instead of merely transplanting Western science - a problematic practice from the Republican era - China has now begun to utilize modern biotechnology to solve indigenous and national problems. The country's access to diverse plant germplasm, foreign educated and trained scientists, and substantial government support has facilitated the integration of recombinant DNA technology into China's research and development environment. In fact, China's experience with traditional medicines and its pool of transgenic plant varieties make the country enormously attractive to international businesses and collaborative research projects. Major revisions to the country's patent laws have only increased international interest in China's resource treasurehouse. However, bioethical and technical standards must be implemented and monitored countrywide if China's scientific advances are to be globally accepted and commercialized.

\section{Note on International Collaboration}

China must increase its participation in international collaborative biotechnology education programs and high-technology research, particularly regarding clinical trials for stem cell therapies and any subsequent commercialization of the results.

The knowledge of Chinese science graduate students is often limited to specialized areas (e.g., biomedical engineering). My observations and research noted that the primary complaint made by Chinese university students related to their lack of knowledge in bioinstrumentation, experimental biology, and other scientific sectors outside their major. These gaps are problematic because survey knowledge of medical, agricultural, aquatic, microbial, genomic, and proteomic biotechnology is essential to making biotechnology advances. Although students learn some of these techniques while studying or conducting research abroad, such practical knowledge would be optimally employed before research is undertaken.

I underwent an academic and instructional trip to Beijing and Chongqing in March of 2004 with Prof. Gin Gee of Miramar College. I was part of an instructional team to deliver a collegiate distance education course, "Biotechnology from a Global Perspective," that utilized a WebCT online educational platform to reach an international student body. The course instructed and stimulated discussion about the biotechnological sciences and its impact on the global economy, business practices, public health, social society, and ethical considerations. Using Internet based videostreaming technology, the students viewed guest lectures and resources delivered or prepared by prominent industrialists and academics from well-known institutions such as Harvard, Invitrogen, University of California - San Diego, Illumina, and Chongqing University. In addition, the instructors and external contributors developed Biotech World, a comprehensive web resource on the latest bioscience research and business and societal culture of "biotechnologically-active" countries.

After establishing a Memorandum of Understanding with China's prestigious universities, several students enrolled in the "Global Biotech" course for the spring 2004 term. The participants included graduate and post-doctoral students and faculty members of Chongqing University, Sichuan University, Fourth Military Medical College, and the China Academy of Tradition Chinese Medicine (see Figure 4 for students during an orientation lecture). During the course, the participants openly expressed their opinions on the progress of China's biotechnology sector and the need for bioethical standards, proper funding, and elective graduate education courses. This ex- 


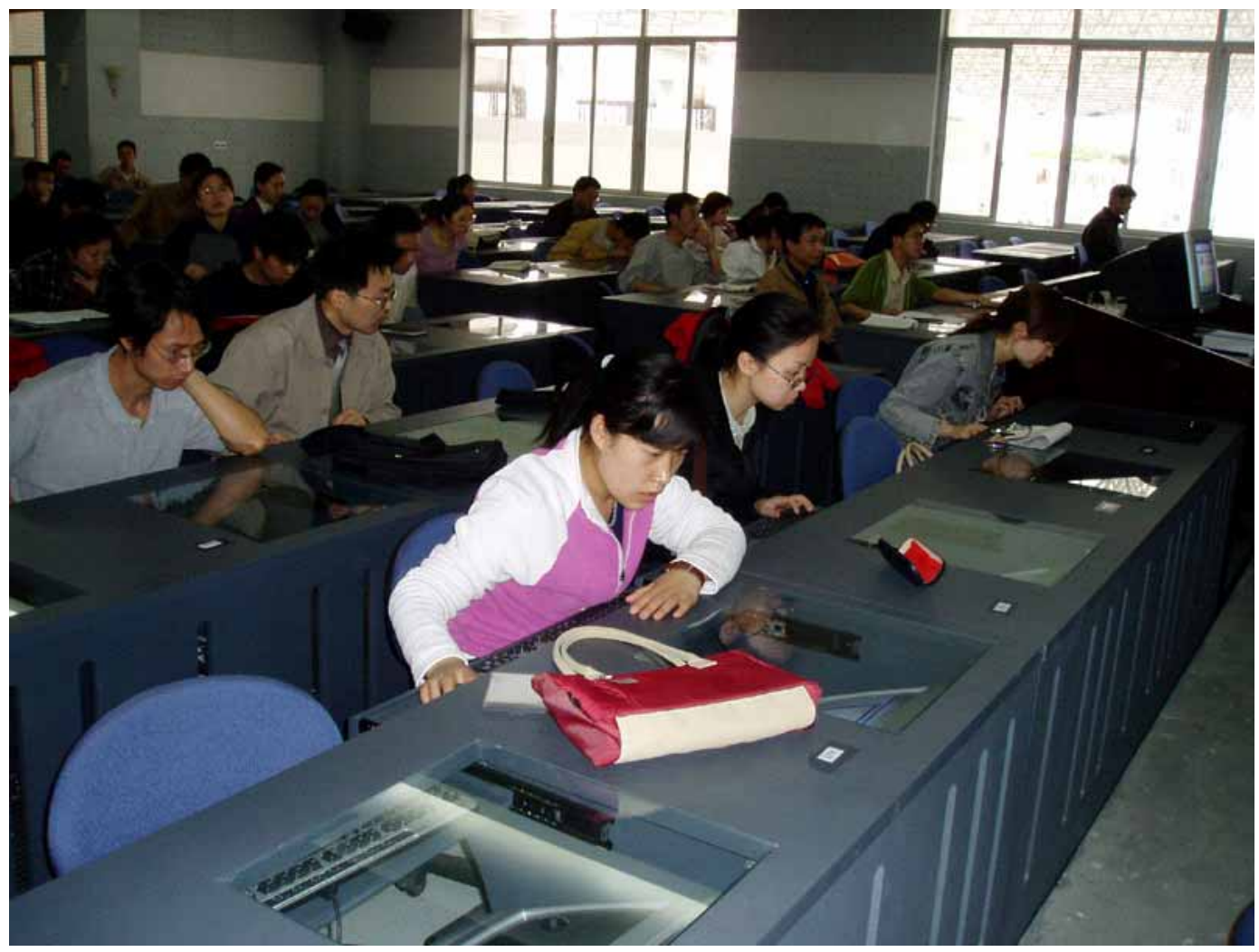

Figure 4. Global Biotechnology distance learning students in China at a computer laboratory in the spring 2004 term.

perience demonstrates that further collaborative education systems should be established with Chinese universities and research institutions, particularly faculty/student exchange programs.

In 1999, the Municipality of Chongqing established a High-Technology Industrialization Office (CQMHTIO) to monitor adherence to national policies and strategies. The organization represents over 150 biotech companies and research institutes, as well as administering important projects in the highly applied sciences. The CQMHTIO views the government as the "head" and enterprise the "main body." Currently, the primary concerns of biotechnology industry executives are commercialization, collaboration with the US, and access to competent scientists. Furthermore, collaborative efforts can be initiated as sponsorship by Western institutions, however, the concern is China's implementation of bioethical practices that are backed by firm financial support. Industry executives may serve as advisory committee members for nearby colleges and universities, and university officials may act on the consulting board for the CQMHTIO. Moreover, our online courses may establish links between the international biotech academic and industry communities, which can facilitate the open exchange of ideas and future collaboration.

Most high-technology projects require expertise in many subjects (e.g., molecular biology, biochemistry, immunology, genetics, transplantation biology, pathology, and clinical medicine). The Chinese government should promote international research and publication because such collaboration will attract scientists to China and increase its scientific reputation. During my visit to China, I met with Dr. Fulong Liao, the Director of Pharmacology at the Institute of Materia Medica, CATCM. I was invited to lecture their doctoral students, staff, and faculty on global biotechnology and on developing collaborative diploma programs (see Figure 5). They have tremendous interest in mass spectrometry and other proteomic experimentations on an ancient TCM herb with specific properties, for example, thermostability. 


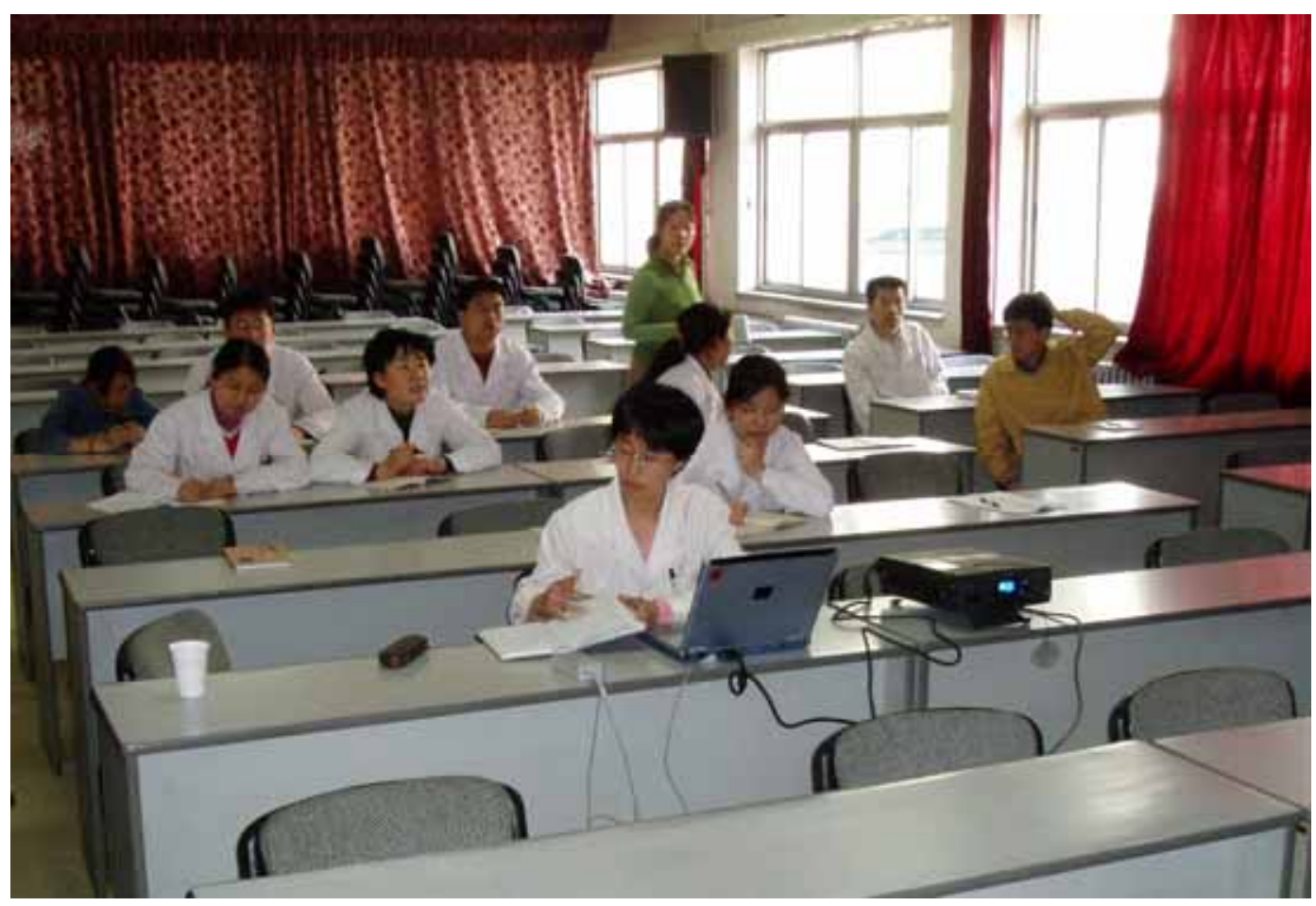

Figure 5. Doctoral students, staff, and faculty of the China Academy of Traditional Chinese Medicine attending Lakhan's lecture on biotechnology.

Collaborative endeavors should be encouraged to bridge China's scientific quest with proper resources, namely, bioinstrumentations and technologies of the West. Moreover, international training programs should be established to impart essential knowledge about experimental design to Chinese researchers who have not studied abroad.

\section{References}

CCP. (1952). The struggle to persist in the Michurinist direction in biological science. People's Daily.

Chen, H. H., Zhou, H. J., \& Fang, X. (2003). Inhibition of human cancer cell line growth and human umbilical vein endothelial cell angiogenesis by artemisinin derivatives in vitro. Pharmacological Research, 48(3), 231-236.

Chen, J. Z., Ji, C. N., Gu, S. H., Li, J. X., Zhao, E. P., Huang, Y., et al. (2004). Over-expression of Bim alpha3: A novel isoform of human Bim, result in cell apoptosis. International Journal of Biochemistry \& Cell Biology, 36(8), 1554-1561.

Chen, P. (1962). Communist China 1961 (Vol. 1). Hong Kong: Union Research Institute.

Chen, Y., He, Z. X., Liu, A., Wang, K., Mao, W. W., Chu, J. X., et al. (2003). Embryonic stem cells generated by nuclear transfer of human somatic nuclei into rabbit oocytes. Cell Research, 13(4), 251-263.

Commission, S. S. a. T. (1986). White paper on science and technology No. 1. Beijing: Joint Publications Research Service - China Science \& Technology.

Consortium, I. H. (2003). The international HapMap project. Nature, 426(6968), 789-796.

Deng, X. (1977). Respect knowledge, respect trained personnel. In P. s. D. Online (Ed.), Selected works of Deng Xiaoping (Vol. II). Beijing: People's Daily Online.

Deng, X. (1978). Speech at the opening ceremony of the National Conference on Science. In P. s. D. Online (Ed.), Selected Works of Deng Xiaoping (Vol. II). Beijing: People's Daily Online. 
Doring, O. (2003). China's struggle for practical regulations in medical ethics. Nature Review Genetics, 4(3), 233-239.

Efferth, T., Dunstan, H., Sauerbrey, A., Miyachi, H., \& Chitambar, C. R. (2001). The anti-malarial artesunate is also active against cancer. International Journal of Oncolology, 18(4), 767-773.

Fairbank, W. (1976). Americas cultural experiment, Publication No. 8839. Washington DC: Department of State.

Gao, H., Sun, Y., Wu, Y., Luan, B., Wang, Y., Qu, B., et al. (2004). Identification of beta-Arrestin2 as a G protein-coupled receptor-stimulated regulator of NF-kappaB pathways. Molecular Cell, 14(3), 303317.

Gao, Y., Ma, Y., Li, M., Cheng, T., Li, S. W., Zhang, J., et al. (2003). Oral immunization of animals with transgenic cherry tomatillo expressing HBsAg. World Journal of Gastroenterology, 9(5), 996-1002.

Garver, J. (2003). Review article: Mao's Soviet policies. The China Quarterly, 173, 199-213.

Gershon, D. (2003). Complex political, ethical and legal issues surround research on human embryonic stem cells. Nature, 422(6934), 928-929.

Glad, J. (2003). Herman J. Muller's 1936 letter to Stalin. The Mankind Quarterly, XLIII(3).

Hamer, D., \& Kung, S.-d. (1989). Biotechnology in China. Washington DC: National Academy Press.

Hao, Z. (1997). May 4th and June 4th compared. Journal of Contemporary China, 6(14), 79-100.

Hogan, B., Beddington, R., Costantini, F., \& Lacy, E. (1994). Manipulating the mouse embryo. New York: Cold Spring Harbor Laboratory Press.

Hossfeld, U., \& Olsson, L. (2002). From the modern synthesis to Lysenkoism, and back? Science, 297, 5556.

Hua, J., Xing, Y., Wu, W., Xu, C., Sun, X., Yu, S., et al. (2003). Single-locus heterotic effects and dominance by dominance interactions can adequately explain the genetic basis of heterosis in an elite rice hybrid. Proceedings of the National Academy of Sciences of the United States of America, 100(5), 2574-2579.

Huang, J., Rozelle, S., Pray, C., \& Wang, Q. (2002). Plant biotechnology in China. Science, 295(5555), 674-676.

Jia, H., \& Louet, S. (2004). China pushes liver proteomics. Nature Biotechnology, 22(2), 136.

Jia, W., Gao, W., \& Tang, L. (2003). Antidiabetic herbal drugs officially approved in China. Phytotherapy Research, 17(10), 1127-1134.

Joseph, A. E., \& Phillips, D. R. (1999). Ageing in rural China: Impacts of increasing diversity in family and community resources. Journal of Cross-Cultural Gerontology, 14(2), 153-168.

Lau, G. K., He, M. L., Fong, D. Y., Bartholomeusz, A., Au, W. Y., Lie, A. K., et al. (2002). Preemptive use of lamivudine reduces hepatitis B exacerbation after allogeneic hematopoietic cell transplantation. Hepatology (Baltimore, Md.), 36(3), 702-709.

Lei, X. (1998). 15 new projects bolster basic research. Science, 282(5397), 2171.

Li, D. M., Xiao, Y. H., Luo, M., Hou, L., Luo, X. Y., Luo, K. M., et al. (2003). [Cloning and characterization of the PTS2 receptor gene (GhPex7) from cotton (Gossypium hirsutum L.)]. Yi Chuan Xue Bao, 30(9), 823-829.

Li, F. W., Zhang, L. S., Liu, H., Cai, Y. C., Pan, J. H., Jia, X. Y., et al. (2001). [Study of protective effect of leech, radix Salviae miltiorrhizae and its composite recipe on vascular endothelial cells in rats with blood stasis syndrome]. Zhongguo Zhong Yao Za Zhi, 26(10), 703-706.

Li, X., Wang, X. D., Zhao, X., \& Dutt, Y. (2004). Improvement of cotton fiber quality by transforming the acsA and acsB genes into Gossypium hirsutum L. by means of vacuum infiltration. Plant Cell Reports, 22(9), 691-697. 
Lui, J. (2001). Patenting biotechnology inventions in China. Nature Biotechnology, 19(1), 83-84.

Ma, S. Y., Au, W. Y., Ng, I. O., Lie, A. K., Leung, A. Y., Liang, R., et al. (2004). Hepatitic graft-versushost disease after hematopoietic stem cell transplantation: Clinicopathologic features and prognostic implication. Transplantation, 77(8), 1252-1259.

MacFarquhar, R. (1974). The origins of the cultural revolution (Vol. 1). New York: Columbia University Press.

McPherson, J. D., Marra, M., Hillier, L., Waterston, R. H., Chinwalla, A., Wallis, J., et al. (2001). A physical map of the human genome. Nature, 409(6822), 934-941.

Meisner, M. (1999). Mao's China and after. New York: The Free Press.

Peishan, L. (1988). Genetics in China: The Qingdao Symposium of 1956. ISIS, 79, 227-236.

Peishan, L., Qingzhe, M., Qinghe, H., \& Shun'e, H. (1985). Hundred schools contending - The road that must be followed for the development of science. Beijing: Commercial Press.

Saich, T. (1989). China's science policy in the 1980s. Atlantic Highlands, NJ: Humanities Press.

Schneider, L. (2003). Biology and revolution in twentieth-century China. Lanham, MD: Rowman \& Littlefield Publishers, Inc.

Sha, J. H., Zhou, Z. M., Li, J. M., Lin, M., Zhu, H., Zhou, Y. D., et al. (2003). Expression of a novel bHLH-Zip gene in human testis. Asian Journal of Andrology, 5(2), 83-88.

Spence, J. D. (1990). The search for modern China. New York: WW Norton.

Sun, Z., Ming, L., Zhu, X., \& Lu, J. (2002). Prevention and control of hepatitis B in China. J Medical Virology, 67(3), 447-450.

Temple, R. (1986). The genius of China. New York: Simon and Schuster.

Unschuld, P. U. (1985). Medicine in China: A history of ideas. Berkeley: University of California Press.

White, N. J. (1996). Current concepts: The treatment of malaria. The New England Journal of Medicine, 335(11), 800-806.

Wu, Y. Z., Li, J. T., Mou, Z. R., Fei, L., Ni, B., Geng, M., et al. (2003). Oral immunization with rotavirus VP7 expressed in transgenic potatoes induced high titers of mucosal neutralizing IgA. Virology, 313(2), 337-342.

Xinhuanet. (2004). Beijing suspends draft animal welfare rule. China View.

Xu, Z.-H., \& Bai, S.-N. (2002). Impact of biotechnology on agriculture in China. Trends in Plant Science, 7(8), 374-375.

Yang, Y., Wang, W., Cleaves, R., Zahurak, M., Cheng, L., Civin, C. I., et al. (2002). Acceleration of G(1) cooperates with core binding factor beta-smooth muscle myosin heavy chain to induce acute leukemia in mice. Cancer Research, 62(8), 2232-2235.

Yao, J., Pang, Y., Qi, H., Wan, B., Zhao, X., Kong, W., et al. (2003). Transgenic tobacco expressing Pinellia ternata agglutinin confers enhanced resistance to aphids. Transgenic Research, 12(6), 715-722.

Yao, J. H., Zhao, X. Y., Liao, Z. H., Lin, J., Chen, Z. H., Chen, F., et al. (2003). Cloning and molecular characterization of a novel lectin gene from Pinellia ternata. Cell Research, 13(4), 301-308.

Yao, Z. X., Qin, M. L., Liu, J. J., Chen, X. S., \& Zhou, D. S. (2004). In vitro cultivation of human fetal pancreatic ductal stem cells and their differentiation into insulin-producing cells. World Journal Gastroenterology, 10(10), 1452-1456.

Yin, Z., Plader, W., \& Malepszy, S. (2004). Transgene inheritance in plants. Journal of Applied Genetics, 45(2), 127-144.

Yu, J., Hu, S., Wang, J., Wong, G. K., Li, S., Liu, B., et al. (2002). A draft sequence of the rice genome (Oryza sativa L. ssp. indica). Science, 296(5565), 79-92. 
Zedong, M. (1977). On the ten major relationships. In M. Zedong (Ed.), Selected works of Mao Zedong (Vol. 5, pp. 299-300). Beijing.

Zhai, W., Chen, C., Zhu, X., Chen, X., Zhang, D., Li, X., et al. (2004). Analysis of T-DNA- Xa21 loci and bacterial blight resistance effects of the transgene Xa21 in transgenic rice. Theoretical and Applied Genetics.

Zhang, Q. (1999). China: agricultural biotechnology opportunities to meet the challenges of food production. Paper presented at the Agricultural Biotechnology and the Poor, Washington, DC.

Zhou, C., Yu, Z., Li, R., \& Tian, Z. (2001). The principle and technique of using Chinese drugs in the treatment of hypertension. Journal of Traditional Chinese Medicine, 21(1), 7-11.

Zhou, E. (1957, June 19). On the correct handling of contradictions among the people. People's Daily.

\section{Biography}

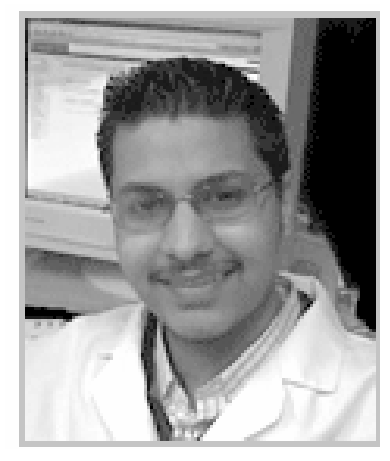

Dr. Shaheen Emmanuel Lakhan is a biotechnology educator, global philanthropist, biomedical research scientist, and administrator of a host of projects in bioethics, psychiatry, proteomics, emergency response, and open-access policy -- to name a few disciplines. He underwent extensive didactic and research based training, completing undergraduate and graduated programs in biochemical sciences, education (educational technology), applied proteomics, medical sciences, and several interdisciplinary fields. He has a well-rounded educational palate from an international perspective by studying in Saint Petersburg - Russia, Queensland - Australia, Haifa - Israel, and in Los Angeles, Boston, New Britain, and New York - USA.

As the Executive Director of the Global Neuroscience Initiative Foundation, Dr. Lakhan oversees the operations, charitable interests, affiliations, and sponsorships of the non-profit charity organization established for the sole benefit of furthering neurological and psychiatric research, patient welfare, and education -- psychological, biochemical, sociological or historical in nature.

During an academic mission to China, Dr. Lakhan collaborated with many government sponsored and private research institutions to further international biotechnology. He was instrumental in co-implementing a multiphase scheme for international biotechnology education and business entrepreneurship. Currently, he is cooperating with the Chinese FDA for distance science education and revamping his course offerings. 